\title{
Evaluating the lower-tropospheric COSMIC GPS radio occultation sounding quality over the Arctic
}

\author{
Xiao Yu' ${ }^{1}$, Feiqin $\mathrm{Xie}^{1}$, and Chi O. Ao ${ }^{2}$ \\ ${ }^{1}$ Department of Physical and Environmental Sciences, Texas A\&M University - Corpus Christi, \\ Corpus Christi, Texas 78412, USA \\ ${ }^{2}$ Jet Propulsion Laboratory, California Institute of Technology, Pasadena, California 91109, USA \\ Correspondence: Feiqin Xie (feiqin.xie@tamucc.edu)
}

Received: 7 July 2017 - Discussion started: 4 October 2017

Revised: 23 January 2018 - Accepted: 5 February 2018 - Published: 11 April 2018

\begin{abstract}
Lower-tropospheric moisture and temperature measurements are crucial for understanding weather prediction and climate change. Global Positioning System radio occultation (GPS RO) has been demonstrated as a high-quality observation technique with high vertical resolution and subkelvin temperature precision from the upper troposphere to the stratosphere. In the tropical lower troposphere, particularly the lowest $2 \mathrm{~km}$, the quality of RO retrievals is known to be degraded and is a topic of active research. However, it is not clear whether similar problems exist at high latitudes, particularly over the Arctic, which is characterized by smooth ocean surface and often negligible moisture in the atmosphere. In this study, 3-year (2008-2010) GPS RO soundings from COSMIC (Constellation Observing System for Meteorology, Ionosphere, and Climate) over the Arctic (65$90^{\circ} \mathrm{N}$ ) show uniform spatial sampling with average penetration depth within $300 \mathrm{~m}$ above the ocean surface. Over $70 \%$ of RO soundings penetrate deep into the lowest $300 \mathrm{~m}$ of the troposphere in all non-summer seasons. However, the fraction of such deeply penetrating profiles reduces to only about $50-60 \%$ in summer, when near-surface moisture and its variation increase. Both structural and parametric uncertainties of GPS RO soundings were also analyzed. The structural uncertainty (due to different data processing approaches) is estimated to be within $\sim 0.07 \%$ in refractivity, $\sim 0.72 \mathrm{~K}$ in temperature, and $\sim 0.05 \mathrm{~g} \mathrm{~kg}^{-1}$ in specific humidity below $10 \mathrm{~km}$, which is derived by comparing RO retrievals from two independent data processing centers. The parametric uncertainty (internal uncertainty of RO sounding) is quantified by comparing GPS RO with near-coincident radiosonde and European Centre for Medium-Range Weather Forecasts
\end{abstract}

(ECMWF) ERA-Interim profiles. A systematic negative bias up to $\sim 1 \%$ in refractivity below $2 \mathrm{~km}$ is only seen in the summer, which confirms the moisture impact on GPS RO quality.

\section{Introduction}

Over the Arctic, the surface temperature has increased twice as much as the global average rate in the past 100 years (Bernstein et al., 2007; Chae et al., 2015; Najafi et al., 2015), indicated by the decline of sea ice cover. The change of the Arctic climate (e.g., temperature) along with the decline of sea ice cover is expected to affect the global climate (Vihma, 2014). The lower troposphere is one of the most critical components of the Arctic climate system, which has been intensely investigated by various observations (e.g., in situ balloon sounding; ground-based, airborne, and satellite remote sensing). However, the lack of continuous highvertical-resolution measurement in the Arctic lower troposphere impedes our understanding of the complex physical processes that controls the air-sea-ice interaction, which is the key to improving Arctic weather forecasting and climate prediction.

Traditional radiosonde balloon soundings have long been the most reliable for sensing the atmospheric properties (e.g., temperature, pressure, and humidity) with high vertical resolution (Pelliccia et al., 2011) and widely used to calibrate and validate the satellite-borne retrievals (John and Buehler, 2005; Kuo et al., 2005). Over the Arctic, most of the radiosondes are only sparsely available over the land near the 
Arctic Circle, with only a few over the ocean from a handful of field campaigns. The ground-based and airborne remote sensing also suffers a limitation in spatial and temporal coverage over the Arctic. The satellite remote sensing offers the opportunity for uniform observation over the Arctic. Passive infrared sounders - such as AIRS (on Aqua), IASI (on MetOp A and B), and CrIS (on Suomi NPP) - provide nearly daily and global vertical atmospheric profiles of temperature and moisture with $\sim 1$ to $2 \mathrm{~km}$ vertical resolution. However they cannot profile beneath the clouds that cover the Arctic Ocean up to $90-95 \%$ of the time in summer months and around 50\% in winter (Zygmuntowska et al., 2012). Microwave sounders, such as the AMSU-A (on Aqua) and ATMS (on Suomi NPP), could sense below the clouds but also have coarse vertical resolution $(\sim 1-2 \mathrm{~km})$ in the lower troposphere and encounter large uncertainty over land due to limited knowledge of the land emissivity (Deng et al., 2009; Weng et al., 2012).

Since the advent of the Global Positioning System (GPS) radio occultation (RO) technique in the early 1990s, the RO soundings have demonstrated a high-quality observation with sub-kelvin temperature precision (Kursinski et al., 1997; Melbourne, 2004; Healy et al., 2005). Since the launch of the six-satellite Constellation Observing System for Meteorology, Ionosphere, and Climate (COSMIC), GPS RO has provided near-real-time, high-vertical-resolution, uniformly distributed global soundings of atmospheric bending angle and refractivity (Anthes et al., 2008) from the stratosphere down to near the surface in all weather conditions. GPS RO bending angle and refractivity measurements have been operationally assimilated into global weather forecasting models and demonstrate significant positive impact especially over the upper troposphere and above the open ocean (Healy et al., 2005; Cucurull et al., 2008). GPS RO measurements are also considered for global climate benchmark monitoring (Ho et al., 2009; Steiner et al., 2013) for their self-calibration and long-term stability (Steiner et al., 2013). Moreover, GPS RO has demonstrated its capability to observe the lower troposphere (Sokolovskiy et al., 2006a, 2010) and the planetary boundary layer (PBL; von Engeln et al., 2005; Sokolovskiy et al., 2007; Ao et al., 2012; Xie et al., 2012; Ho et al., 2015). The GPS RO measurement could fill the gap in observing the lower troposphere over the Arctic (e.g., Ganeshan and Wu, 2015; Chang et al., 2017). Nevertheless, the uncertainty of RO sounding increases in the lower troposphere especially within the PBL, which remains largely uncharacterized over the remote Arctic Ocean.

One issue of GPS RO sounding for the lower troposphere lies in that not all the RO profiles penetrate down to the surface (Ao et al., 2012; Xie et al., 2012). The limitedpenetration issue could be resulting from the early termination of RO sounding due to the topographic blocking of RO signals grazing the Earth's surface. In addition, the corruption of RO signal due to the increasing receiver tracking error in the lower troposphere could also lead to early termination of the sounding profiles before reaching the surface. To measure the very shallow surface inversion that is often observed over the Arctic Ocean (Tjernström et al., 2014) requires very deep penetration of RO sounding. The implementation of the open-loop tracking technique has significantly improved the fraction of soundings reaching within $1 \mathrm{~km}$ of the Earth's surface (Ao et al., 2009). However, a significant fraction of the RO soundings still cannot reach the lowest $500 \mathrm{~m}$ above the surface, which could be especially problematic for sensing the Arctic shallow PBL and warrants further studies.

Beyond the penetration issue, the structural uncertainty and parametric uncertainty affecting RO sounding quality should also be investigated. The structural uncertainty arises from different approaches of constructing the dataset from the same raw data, whereas the parametric uncertainty is the uncertainty for the chosen approach in the presence of a finite sample of data (Thorne et al., 2005). Note that the NASA Jet Propulsion Laboratory (JPL) and the University Corporation for Atmospheric Research (UCAR) are two major independent COSMIC RO retrievals centers. The two centers use different inversion algorithms to derive the RO parameters from the same raw COSMIC RO measurements. The statistical comparisons between JPL and UCAR retrievals will shed some lights on the structural uncertainty of the COSMIC RO data. Ho et al. (2009) and Steiner et al. (2013) investigated the structure uncertainty of RO soundings from the upper troposphere to the lower stratosphere ( $\sim 8$ to $25 \mathrm{~km})$, among different data centers (including JPL, UCAR, and several European centers), and revealed very small uncertainty (e.g., less than $0.06 \mathrm{~K}$ in temperature). In this study, the focus will be on assessing the structural uncertainty in the lower troposphere over the Arctic. In addition, the parametric uncertainty of COSMIC RO soundings will also be evaluated by comparing with independent radiosonde observations as well as the global reanalysis. A better understanding of the penetration issue along with the quantification of both structural and parametric uncertainties will help improve RO retrievals and further RO science applications.

This paper will focus on COSMIC RO soundings in the lower troposphere over the Arctic $\left(65-90^{\circ} \mathrm{N}\right)$. Section 2 describes the COSMIC, radiosonde, and global reanalysis data used for this study. Section 3 details the definition of RO penetration depth and the RO retrieval difference between JPL and UCAR data centers. Section 4 presents seasonal variation of penetration depth over the Arctic, the RO structure and parametric uncertainties derived from the inter-center $\mathrm{RO}$ retrieval comparison between JPL and UCAR, and the comparison of RO retrievals with radiosonde and global reanalysis. Section 5 contains the summary and conclusions.

\section{Data}

This study analyzed Level 2 (e.g., refractivity, temperature, and humidity) COSMIC RO data over the Arctic 
Table 1. The properties of the COSMIC RO, radiosonde, and ERA-Interim.

\begin{tabular}{lrrllll}
\hline \multicolumn{2}{c}{ Data type } & Date & Parameters & Region & $\begin{array}{l}\text { Vertical } \\
\text { resolution }\end{array}$ & $\begin{array}{l}\text { Horizontal } \\
\text { resolution }\end{array}$ \\
\hline COSMIC RO & UCAR & $2007-2010$ & $\begin{array}{l}\text { Refractivity, temperature } \\
\& \text { humidity }\end{array}$ & $65-90^{\circ} \mathrm{N}$ & $\sim 200 \mathrm{~m}$ & $\sim 200 \mathrm{~km}$ \\
\hline JPL & $2007-2010$ & & & & \\
\hline Radiosonde & ASCOS & $03 / 08-$ & $\begin{array}{l}\text { Pressure, temperature } \\
\text { \& humidity }\end{array}$ & $\sim 78-87^{\circ} \mathrm{N}$ & $\sim 5-100 \mathrm{~m}$ \\
\hline ERA-Interim $^{\mathrm{b}}$ & & $2007-2008$ & $\begin{array}{l}\text { Pressure, temperature } \\
\& \text { humidity }\end{array}$ & $65-90^{\circ} \mathrm{N}$ & $\begin{array}{l}60 \text { layers (with } 28 \text { layers } \\
\text { below } \sim 10 \mathrm{~km})\end{array}$ & $\begin{array}{l}0.75^{\circ} \text { latitude } \times \\
0.75^{\circ} \text { longitude }\end{array}$ \\
\hline
\end{tabular}

${ }^{a}$ ASCOS: Arctic Summer Cloud Ocean Study field campaign. ${ }^{b}$ ERA-Interim: European Centre for Medium-Range Weather Forecasts Reanalysis Interim.

$\left(65-90^{\circ} \mathrm{N}\right)$ from two major RO data processing centers in the United States: JPL (http://genesis.jpl.nasa.gov/genesis/) and UCAR (www.cosmic.ucar.edu/cdaac/). In addition, radiosonde soundings from the Arctic Summer Cloud Ocean Study (ASCOS) and the European Centre for Medium-Range Weather Forecasts (ECMWF) Reanalysis Interim (ERAInterim, ERA-I) data over the Arctic are also used. The properties of the COSMIC RO, radiosonde, and ERA-Interim are listed in Table 1.

\subsection{COSMIC GPS RO}

Three years of COSMIC RO soundings from both JPL and UCAR over the Arctic $\left(65-90^{\circ} \mathrm{N}\right)$ were analyzed, with a special emphasis on the troposphere (e.g., below $\sim 10 \mathrm{~km}$ ). The post-processed version of the JPL retrievals and the UCAR retrievals from 2008 to 2010 were used, where a consistent retrieval algorithm has been implemented throughout the data processing period. The COSMIC RO data are grouped into four seasons: winter - DJF (December-January-February); spring - MAM (MarchApril-May); summer - JJA (June-July-August); and fall SON (September-October-November). Note that the month of December in the winter season is from the previous year (e.g., DJF 2008 denoted as December 2007, January 2008, and February 2008). The JPL retrieval algorithm has been detailed in Hajj et al. (2002) and Ao et al. (2012), whereas the UCAR retrieval algorithm can be found in Kuo et al. (2004). Different calibration (e.g., orbit and clock calibration; Wickert, 2002; Schreiner et al., 2009), retrieval algorithm, and quality control procedure (e.g., Ho et al., 2009) lead to some differences in the total throughput of COSMIC RO soundings from the two data centers. JPL retrievals generally yield slightly fewer soundings than UCAR retrievals. A total of 112156 and 129538 RO profiles are retrieved from JPL and UCAR, respectively. Additional discussions on the processing differences can also be found in Ho et al. $(2009,2012)$ and Steiner et al. (2013).

\subsection{Radiosonde and global reanalysis}

High-resolution radiosonde soundings from the ASCOS field campaign (red dots) throughout the cruise in the Atlantic sector of the Arctic from 3 August to 7 September 2008 (Tjernström et al., 2014) and the COSMIC RO (e.g., UCAR) soundings distribution (blue diamond) during the same time period over $75-90^{\circ} \mathrm{N}$ are shown in Fig. 1. Detailed description of ASCOS including the instrumentation and measurements can be found in Tjernström et al. (2014). Radiosondes were launched from the helipad of the icebreaker four times a day at approximately 00:00, 06:00, 12:00, and 18:00 Coordinated Universal Time (UTC). A total of 145 soundings were collected throughout the entire period of the cruise. Only one sounding was discarded due to missing latitude and longitude information. Each profile was interpolated onto uniform vertical levels with intervals increasing from $5 \mathrm{~m}$ in the lowest $1 \mathrm{~km}$ of the troposphere to $100 \mathrm{~m}$ in the stratosphere (Birch et al., 2012). In addition, the ERA-I reanalysis profiles over the Arctic were also analyzed. The ERA-I applied a T255 grid scheme with $0.75^{\circ}$ horizontal grids $(\sim 83 \mathrm{~km}$ near the Equator or $\sim 14 \mathrm{~km}$ near latitude $\sim 80^{\circ} \mathrm{N}$ ), and 60 vertical layers (Dee et al., 2011).

\section{Methodology}

In this section, COSMIC RO sounding penetration depth, the RO retrieval algorithm difference between JPL and UCAR centers, as well as the equal-area-gridding technique used for this study will be discussed.

\subsection{Penetration depth of COSMIC RO soundings}

One major limitation of using GPS RO sounding to study the lower troposphere is that not all the RO profiles reach the surface. Here we define the "penetration depth" as the minimum height of each individual RO sounding above the local surface. Note that the GPS height is the height above the mean sea level (MSL), which is referred to as the height above the 


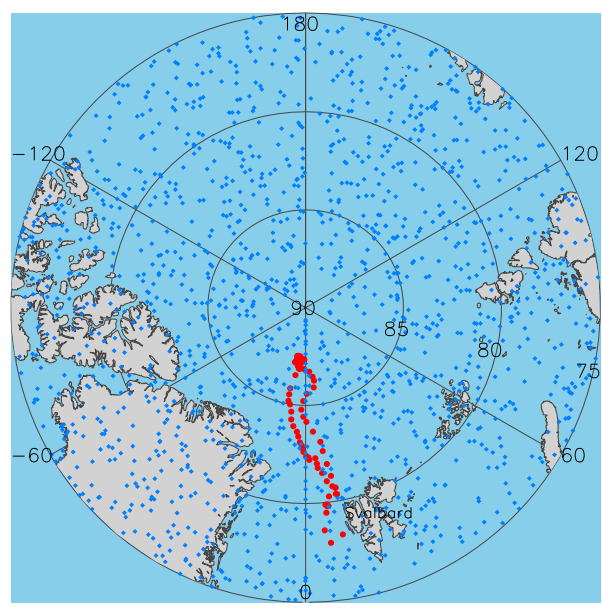

Figure 1. Radiosonde soundings track (red dot) during the ASCOS field campaign from 3 August to 7 September 2008, and the COSMIC RO (e.g., UCAR) soundings distribution (blue diamond) during the same time period over $75-90^{\circ} \mathrm{N}$.

geoid, i.e., the equipotential gravity surface height from a standard gravity model such as the Earth Gravity Model 1996 (EGM96). The high-resolution digital terrain elevation data $\left(0.16^{\circ}\right.$ grid $)$ used in this paper are also in reference to above the geoid. Thereafter, the penetration depth in this paper will be the GPS height above the local surface after subtracting the terrain elevation.

In the RO retrieval, the penetration depth of an individual occultation sounding is affected by the quality of the GPS RO signal at the receiver and the quality control criteria used. Several factors could result in the degradation of RO signal that leads to earlier termination of RO profiles before the sounding reaches the local surface, i.e., a positive penetration depth. For example, the topography along the GPS and the RO receiver line of sight could block the RO signals and lead to the early termination of the RO sounding. In addition, the RO signal could be degraded due to receiver signal tracking issues attributed to the presence of large vertical moisture variation in the lower troposphere (Ao et al., 2012).

In the JPL retrieval system, the ending of an RO sounding (i.e., the penetration depth) is determined as the transition point where the RO signal quickly degrades into an unusable noisy regime by fitting a step function to the transformed signal amplitude after the canonical transform inversion algorithm (Ao et al., 2012). A similar approach is applied in the UCAR retrieval as well but using a different transformed signal through the full-spectrum inversion (FSI) algorithm (Jensen et al., 2003; Kuo et al., 2004). With the implementation of open-loop tracking in the COSMIC mission, the receiver tracking errors in the lower troposphere have been significantly reduced (Ao et al., 2003; Sokolovskiy et al., 2006a, b). However, the non-uniform RO penetration depth across the globe remains and requires further investigation (Ao et al., 2012; Xie et al., 2012). It is important to note that the ver- tical resolution of the Level $2 \mathrm{RO}$ refractivity retrievals in the lower troposphere is limited to be $\sim 200 \mathrm{~m}$ due to the vertical smoothing of the retrieval profiles. Therefore, the penetration depth at or below $100 \mathrm{~m}$ is essentially as good as reaching the surface.

\subsection{COSMIC RO retrieval algorithm difference between JPL and UCAR data centers}

The detailed description of the GPS RO technique has been covered extensively in several papers (Kursinski et al., 1997; Hajj et al., 2002; Anthes et al., 2008). Here we only summarize the key concepts of the retrieval processes. GPS RO senses the atmosphere by tracking the GPS radio signals that traverse the atmosphere as a moving receiver sets (or rises) behind the horizon relative to the transmitting satellite. The radio wave is refracted, and its travel time is delayed due to the variations of refractivity of the atmosphere. GPS RO precisely measures phase and amplitude of GPS signals that traverse the Earth's atmosphere. After the phases are calibrated by removing the GPS and LEO clock errors, a time series of excess phase at both GPS frequencies (e.g., L1 and L2) is derived. Then under the assumption of a local spherically symmetric atmosphere, the vertical profile of the bending angle $(\alpha)$ and the refractivity index $(n)$ can be derived. In a neutral atmosphere, the refractivity $\left(N=(n-1) \times 10^{6}\right)$ measured by GPS RO is related to pressure ( $P$ in mbar), temperature ( $T$ in $\mathrm{K})$, and water vapor partial pressure ( $P_{\mathrm{w}}$ in mbar) as the following Eq. (1) (Smith and Weintraub, 1953):

$N=77.6 \frac{P}{T}+3.73 \times 10^{5} \frac{P_{\mathrm{w}}}{T^{2}}$.

Based on the RO refractivity, the temperature and humidity profiles can be derived with certain external information. In the upper troposphere and above, the second term (the socalled "wet term") on the right-hand side of the refractivity Eq. (1) can be neglected. The so-called dry temperature $\left(T_{\text {dry }}\right)$ can be derived as follows:

$T_{\text {dry }}=77.6 \frac{P_{\text {dry }}}{N}$.

As the saturation vapor pressure decreases rapidly with decreasing temperature according to the Clausius-Clapeyron equation, the water vapor pressure $P_{\mathrm{w}}$ can be neglected in the upper troposphere, where temperature is low (e.g., $T<250 \mathrm{~K}$; Kursinski et al., 2000; Hajj et al., 2002; Melbourne, 2004). Given the pressure (or more strictly, the dry pressure, $P_{\text {dry }}$, derived from the hydrostatic balance) and the RO refractivity profiles, the temperature can be retrieved. Accurate temperature profiles can be derived throughout the stratosphere down to the mid-troposphere or even lower altitudes depending on latitudes, where the water vapor is negligible.

In the middle or lower troposphere where the moisture is not negligible, the derivation of temperature and humid- 
ity becomes an underdetermined problem, which is generally referred to as the dry-wet ambiguity problem. To solve this issue, the JPL and UCAR data centers use different approaches.

In the JPL retrieval (e.g., Hajj et al., 2002), the moisture retrieval only starts when the dry temperature is over $250 \mathrm{~K}$, i.e., when the moisture contribution to the refractivity becomes non-negligible (Kursinski et al., 1997). In the temperate and tropical regions where the water vapor is abundant with large uncertainty, the temperature profile from numerical weather prediction (NWP) model analysis usually is relatively better known and thus can be used to aid the water vapor retrieval. In practice, the nearest 6-hourly ECMWF global analysis temperature profiles are interpolated into each RO sounding location as a priori. Given the RO refractivity profile $\left(T_{\mathrm{dry}}>250 \mathrm{~K}\right)$ and the a priori ECMWF temperature profile, the RO water vapor profile can be derived. On the other hand, given the RO refractivity and the a priori ECMWF water vapor profile, the RO temperature profile can also be derived. While the approach is relatively simple, the RO water vapor (or temperature) will contain both measurement uncertainty in RO refractivity and the uncertainty in the a priori ECMWF temperature (or water vapor).

The UCAR data center applied the optimal estimation of the water vapor, temperature, and pressure through a variational method (Kuo et al., 2004). The variational method combines the occultation measurements (e.g., refractivity) with the a priori (or background) atmospheric condition in a statistically optimal way (Zou et al., 1995; Healy and Eyre, 2000). For example, the optimal solution to the state vectors (e.g., $T, P_{\mathrm{w}}$, and $P$ ) can be found by adjusting the state vector elements in a way that is consistent with the estimated background errors, to produce simulated measurement values that fit the observations to within their expected observational errors (Healy and Eyre, 2000).

Both JPL and UCAR temperature and humidity retrievals require the a priori information from models and thus are not independent measurements. Instead, measurements (e.g., refractivity, dry temperature) are model-independent observations. Note that the errors of the geophysical parameters derived from the 1-D-variational method (UCAR) could become more challenging to interpret because the errors are a combination of the a priori model background errors with the RO measurement errors.

\subsection{The equal-area-grid mapping method}

Note that a fixed latitude-longitude grid $\left(2.5^{\circ} \times 2.5^{\circ}\right)$ near the Equator has an area of $\sim 78400 \mathrm{~km}^{2}$, which is equivalent to a square cell with sides of $\sim 280 \mathrm{~km}$. However, the length of the fixed grid longitude is significantly reduced at higher latitude, especially near the polar region. To accommodate such a significant reduction of grid area at higher latitude resulting from the fixed latitude-longitude grid, the equal-area-grid mapping method is applied. A fixed $2.5^{\circ}$ lat- itude interval $(\sim 280 \mathrm{~km})$ is chosen, and each latitude band is evenly divided to have each grid area close to $78400 \mathrm{~km}^{2}$. Therefore, each grid will have a roughly equal area across the polar region with a fixed $2.5^{\circ}$ latitude interval and a variable longitude interval (increasing at higher latitude or toward the poles). The mapping technique will result in only 3 grids within $87.5-90^{\circ} \mathrm{N}$ latitude bands; 9 grids within $85-$ $87.5^{\circ} \mathrm{N}$; and, increasing further south, the maximum of 58 grids within $65-67.5^{\circ} \mathrm{N}$ (Rossow and Schiffer, 1991).

\section{Results and discussions}

In this section, spatial and temporal variation of the COSMIC RO sounding penetration depth, the structural uncertainty and the parametric uncertainty of the RO retrieval will be discussed.

\subsection{Spatial and temporal variation of RO penetration depth}

COSMIC RO refractivity profiles over the Arctic $\left(65-90^{\circ} \mathrm{N}\right)$ from both JPL and UCAR are analyzed. The 3-year (20082010) median seasonal variations of the penetration depth for both centers and their associated RO profile sample numbers are shown in Fig. 2. Both centers show rather homogeneous sampling with $\sim 60-120$ soundings in each equal-area grid (equivalent to the area of a square cell of $280 \mathrm{~km} \times 280 \mathrm{~km}$ ). JPL shows slightly less sounding at each grid than UCAR, which is consistent with the overall smaller sample size.

A very similar geographical pattern of RO penetration depth is seen for both centers in all seasons, with rather uniform deep penetration $(\sim 0-300 \mathrm{~m})$ over the Arctic Ocean and generally poorer penetration over land and islands. The distinctly poorer penetration (i.e., larger penetration depth) in summer than other seasons indicates the degradation of RO retrieval due to the increase of the lower-tropospheric water vapor during the warmer summer season. In addition, central Greenland shows deep penetration (100-300 m) likely due to the relatively flat terrain. Over the land surrounding the Arctic Ocean, the penetration depth varies from 100 to $900 \mathrm{~m}$ with slightly poorer penetration in JPL data, over the northwestern edge of Greenland. It is worth noting that $\sim 100 \mathrm{~m}$ penetration depth is essentially as good as reaching the surface as both JPL and UCAR centers apply $\sim 200 \mathrm{~m}$ vertical smoothing on the RO bending/refractivity retrieval.

Figure 3 further illustrates the seasonal-mean percentage of RO profiles reaching different altitude (binned into $100 \mathrm{~m}$ vertical intervals) above the surface, with land and ocean separated. For both centers, a high percentage of COSMIC RO soundings $(\sim 85-90 \%)$ penetrates below $1 \mathrm{~km}$ in all seasons. But a sharp decrease by $\sim 8-20 \%$ is seen in RO profiles reaching $0.5 \mathrm{~km}$ above the surface. Above $1 \mathrm{~km}$, no significant difference in RO penetration is seen between the land and the ocean. However, a slight decrease in the percentage 


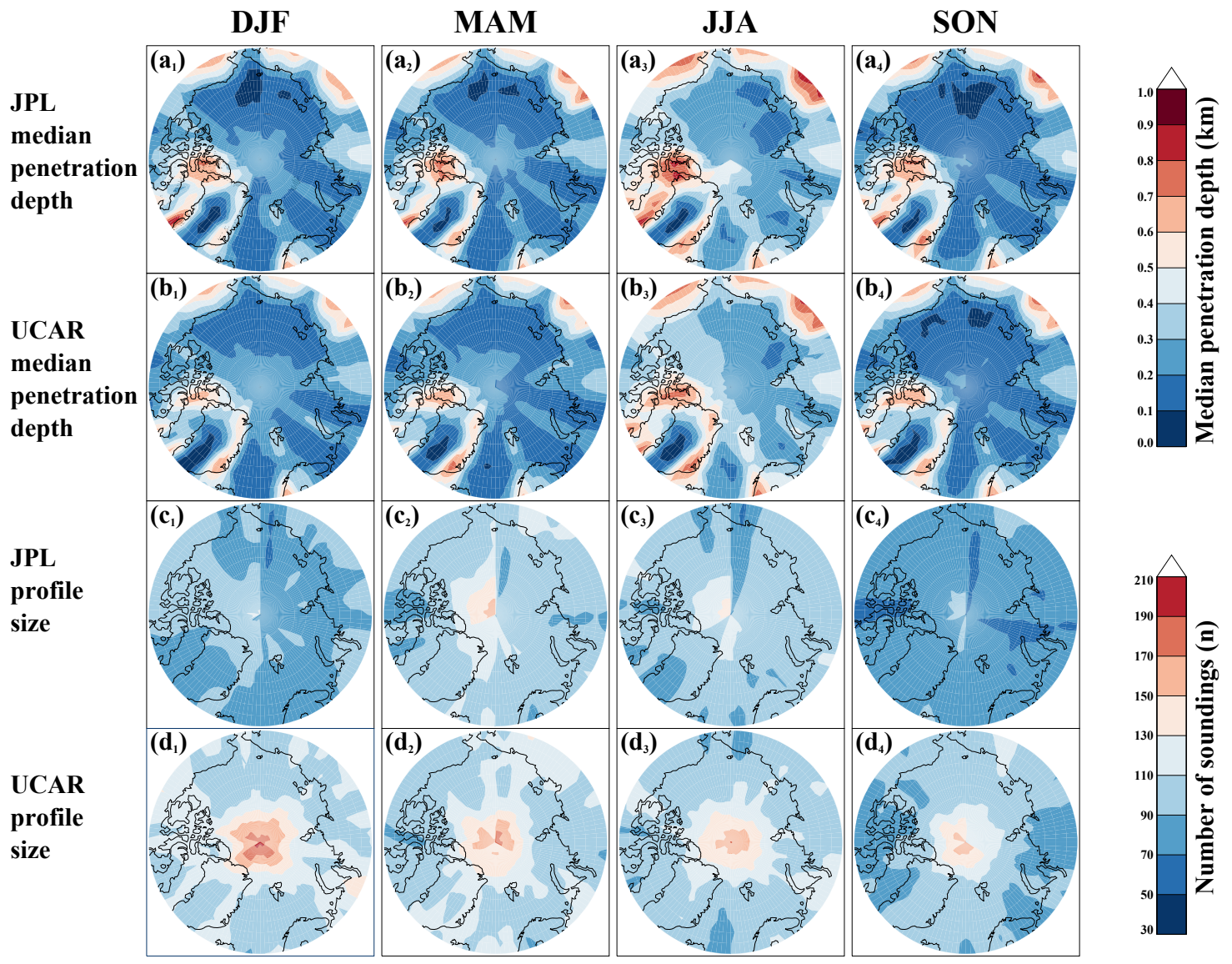

Figure 2. Seasonal median penetration depth of COSMIC RO soundings for JPL $\left(\mathbf{a}_{1}-\mathbf{a}_{4}\right)$ and UCAR $\left(\mathbf{b}_{1}-\mathbf{b}_{4}\right)$, and the corresponding number of soundings in each season for JPL $\left(\mathbf{c}_{1}-\mathbf{c}_{4}\right)$ and UCAR $\left(\mathbf{d}_{1}-\mathbf{d}_{4}\right)$ over the Arctic $\left(65-90^{\circ} \mathbf{N}\right)$ from 2008 to 2010 . Note the equal-area mapping uses the equivalent square cell with sides of $\sim 280 \mathrm{~km}$.

of RO profiles reaching below $1 \mathrm{~km}$ over land could be due to the topography blocking effect.

The UCAR retrieval shows generally a higher percentage of profiles ( $\sim 92-95 \%)$ penetrating down to $1 \mathrm{~km}$ above the surface than the JPL $(\sim 88 \%)$ in all seasons except the summer, when the percentage drops to $\sim 84 \%$ for both centers. UCAR also shows a generally higher percentage of RO soundings extending to the height levels within 0.5 to $1 \mathrm{~km}$, except the summer season, when JPL shows a slightly higher percentage of profiles extending to all levels below $1 \mathrm{~km}$. In addition, JPL also shows a slightly higher percentage of RO profiles extending below $0.3 \mathrm{~km}$ than UCAR in all seasons, with a maximum of $\sim 5 \%$ difference in summer.

The much higher percentage of deeply penetrating RO profiles below $0.5 \mathrm{~km}$ over the very dry Arctic Ocean (65$80 \%$ ) than the moist tropics of 20-30\% (Ao et al., 2012; Xie et al., 2012) strongly indicates that the increase of lowertropospheric moisture could result in larger receiver tracking errors and the early termination of the RO profile. The poorer penetration in the warmer and moister summer Arctic further confirms the moisture impact on the RO penetration issue.

\subsection{Inter-center comparisons between JPL and UCAR retrievals}

To quantify the structural uncertainty of the COSMIC RO soundings over the Arctic $\left(65-90^{\circ} \mathrm{N}\right)$, the RO retrieval difference between JPL and UCAR data centers is analyzed. The RO soundings in both winter (DJF) and summer (JJA) seasons of 2008 are investigated. Although both data centers start from the same Level 1 raw COSMIC measurements, their retrieval algorithms are slightly different in terms of calibration, retrieval, and quality control processes (Ho et al., 2012). A total of 4782 pairs of common soundings in winter (DJF) and 8375 pairs in summer (JJA) of 2008 have been identified.

All RO sounding refractivity, temperature, and specific humidity (e.g., $N, T, q$ ) from both centers are interpolated into $100 \mathrm{~m}$ vertical intervals. The ensemble mean, standard deviation and standard error of the inter-center differences, and the sampling number are shown in Fig. 4. The statistics at three selected altitude ranges (e.g., from the surface up to 3 , 5 , and $10 \mathrm{~km}$ ) are summarized in Table 2 . It is also worth 

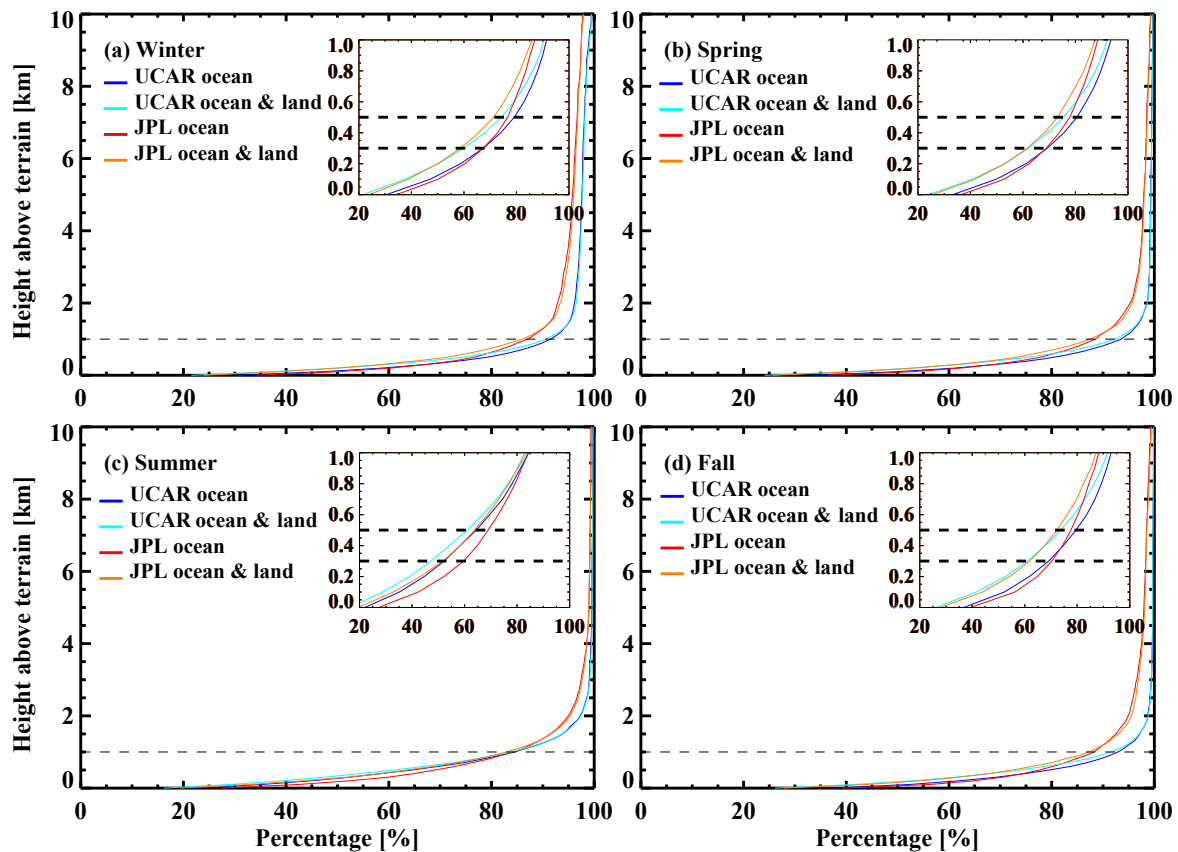

Figure 3. Seasonal-mean percentage of COSMIC RO profiles penetrating into the troposphere above the terrain over the Arctic $\left(65-90^{\circ} \mathrm{N}\right)$. Darker and lighter blue describe UCAR profiles over ocean only and over both ocean and land, respectively. Red and orange describe JPL profiles over ocean only and over both ocean and land, respectively. The inlet plots show the lowest $1 \mathrm{~km}$, with the two dashed lines marking the heights of 0.3 and $0.5 \mathrm{~km}$.

Table 2. Statistical comparison between JPL and UCAR retrievals from COSMIC RO.

\begin{tabular}{lrrr}
\hline Seasonal mean difference & Altitude range & $\begin{array}{r}\text { DJF 2008 } \\
(4782 \text { pairs })\end{array}$ & $\begin{array}{r}\text { JJA 2008 } \\
(8375 \text { pairs })\end{array}$ \\
\cline { 3 - 4 } & $(\mathrm{km})$ & $\mu(\sigma)^{*}$ & $\mu(\sigma)$ \\
\hline$\left(N_{\mathrm{JPL}}-N_{\mathrm{UCAR}}\right) / N_{\mathrm{UCAR}}(\%)$ & $0-3$ & $0.04(0.19)$ & $0.02(0.44)$ \\
& $0-5$ & $0.05(0.18)$ & $0.04(0.38)$ \\
$T_{\mathrm{JPL}}-T_{\mathrm{UCAR}}(\mathrm{K})$ & $0-10$ & $0.06(0.19)$ & $0.07(0.33)$ \\
\hline$q_{\mathrm{JPL}}-q_{\mathrm{UCAR}}\left(\mathrm{g} \mathrm{kg}^{-1}\right)$ & $0-3$ & $0.54(0.45)$ & \\
& $0-5$ & $0.51(0.47)$ & $0.72(0.60)$ \\
& $0-10$ & $0.38(0.40)$ & $0.61(0.62)$ \\
\hline
\end{tabular}

* Note that $\mu$ and $\sigma$ represent mean and standard deviation, respectively.

noting that the significantly decreasing number of common refractivity soundings in the lowest $3 \mathrm{~km}$ is mainly due to the limited RO sounding penetration depth as discussed in Sect. 4.1. The statistics for the lowest $200 \mathrm{~m}$ were discarded due to the significant drop of the number of RO observations near the surface, limited by the $\sim 200 \mathrm{~m}$ vertical resolution of RO retrievals. For the RO temperature and specific humidity profiles, the variation of common sounding numbers at different altitudes is mainly limited by the availability of JPL retrievals. For example, UCAR retrieves both $T$ and $q$ at all altitude where refractivity retrievals are available. However, JPL only retrieves tropospheric temperature at altitudes cooler than a threshold of about $250 \mathrm{~K}$ (see Sect. 3.2), leading to a significant reduction in the number of JPL temperature retrievals in the lower troposphere, especially in the warmer summer season (Fig. 4d). To account for the number of pairs that change with the altitude, the standard error is also computed (i.e., the standard deviation divided by the square root of the sample size), which is an estimation of the difference 

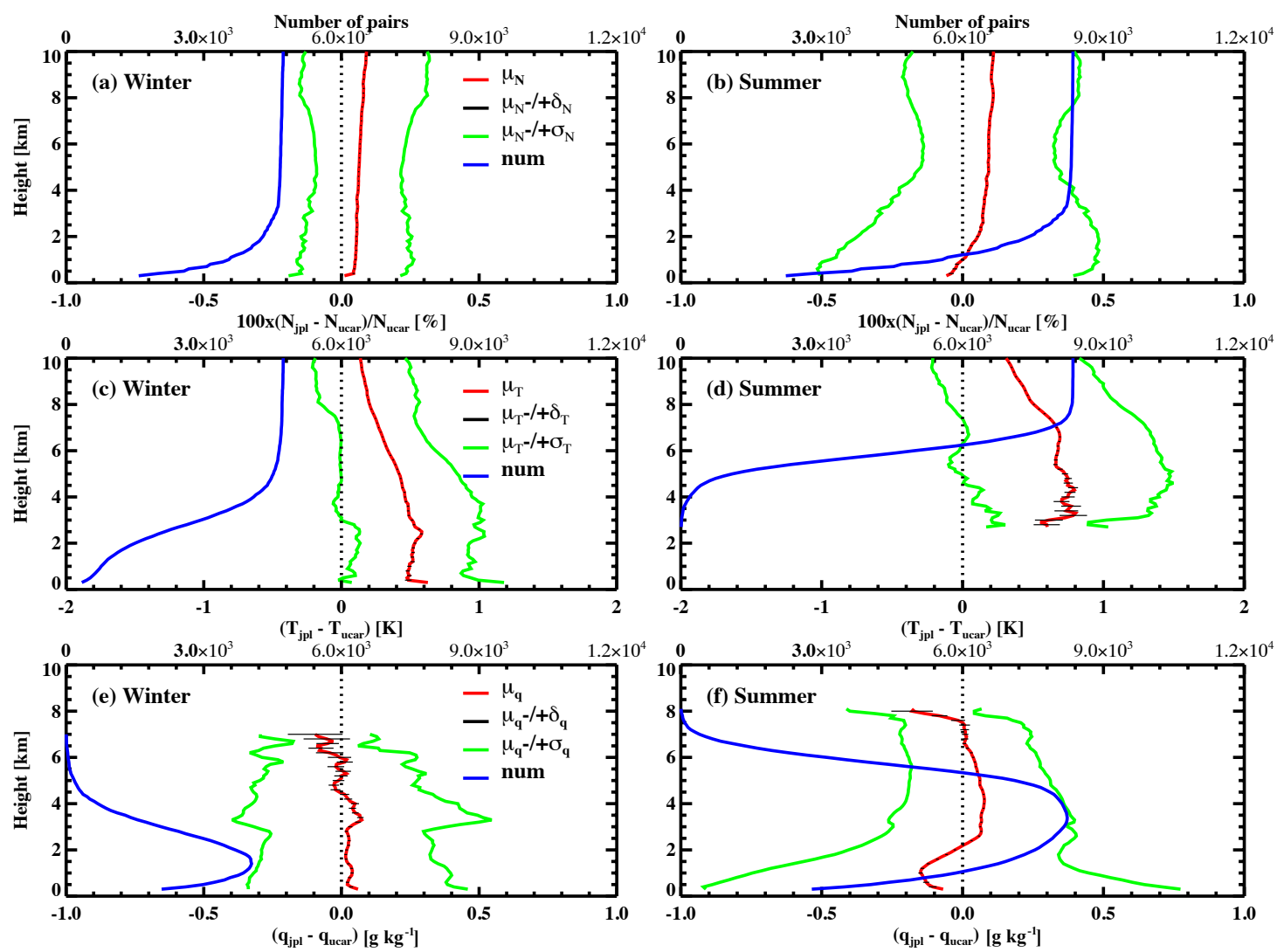

Figure 4. Statistical comparisons of COSMIC RO between JPL and UCAR retrievals are shown in fractional refractivity (a, b), temperature (c, d), and humidity (e, f) over the Arctic $\left(65-90^{\circ} \mathrm{N}\right)$ in winter (DJF, a, c, e) and summer (JJA, b, d, f) of 2008. The mean difference ( $\mu$, red), the mean plus/minus $( \pm) 1$ standard deviation $(\sigma$, green), and standard error $(\delta$, black horizontal bar) for all three parameters are also shown. The number of common sounding pairs varies with heights is shown (blue), with the scale marked on the top of each panel.

of the sample mean from the population mean affected by the sample size.

In winter, small but persistent biases are seen in the JPL retrieval as compared to the UCAR retrieval below $3 \mathrm{~km}$ in refractivity $(\sim 0.04 \%)$, temperature $(0.54 \mathrm{~K})$, and specific humidity $\left(0.03 \mathrm{~g} \mathrm{~kg}^{-1}\right)$, with a standard deviation of $0.19 \%$, $0.45 \mathrm{~K}$, and $0.33 \mathrm{~g} \mathrm{~kg}^{-1}$, respectively. In summer, the difference for refractivity and specific humidity slightly changes, with a mean difference of $0.02 \%$ and $-0.05 \mathrm{~g} \mathrm{~kg}^{-1}$, and a corresponding standard deviation of $0.44 \%$ and $0.50 \mathrm{~g} \mathrm{~kg}^{-1}$, respectively.

The mean fractional refractivity difference between JPL and UCAR is $\sim 0.06$ in winter and $0.07 \%$ in summer below $10 \mathrm{~km}$, which is consistent in magnitude with the intercenter comparison of CHAMP RO data within $8-12 \mathrm{~km}$ over $60-90^{\circ} \mathrm{N}$ (Ho et al., 2009). No significant difference is seen between the winter and the summer. The mean temperature difference is 0.38 in winter and $0.61 \mathrm{~K}$ in summer below $10 \mathrm{~km}$, with a corresponding standard deviation of 0.40 and $0.62 \mathrm{~K}$, respectively. The mean specific humidity difference is 0.03 in winter and $0.002 \mathrm{~g} \mathrm{~kg}^{-1}$ in summer below $5 \mathrm{~km}$, with a corresponding standard deviation of 0.34 and
$0.41 \mathrm{~g} \mathrm{~kg}^{-1}$, respectively. The standard errors are generally small, except when there is a sharp decrease in sample size resulting from fewer JPL temperature retrievals below $5 \mathrm{~km}$ in summer (Fig. $4 \mathrm{~d}$ ) and moisture retrieval above $\sim 3 \mathrm{~km}$ in winter (Fig. 4e). The generally small standard error indicates reliable statistics given the large sample size at most altitude levels.

\subsection{Comparisons of the radiosonde with the RO retrievals and the ERA-I profiles}

To quantify the parametric uncertainty of the COSMIC RO soundings over the Arctic $\left(65-90^{\circ} \mathrm{N}\right)$, both JPL and UCAR retrievals are collocated with a total of 144 radiosonde soundings collected from the ASCOS summer field campaign in 2008. A total of 65 JPL profiles and 68 UCAR profiles were found to be collocated with the radiosondes within $3 \mathrm{~h}$ and $300 \mathrm{~km}$. The ensemble mean difference, standard deviation, and standard errors are shown in Fig. 5. The statistics of the comparisons at three selected altitude ranges (e.g., 3, 5, and $10 \mathrm{~km}$ from the surface) are listed in Table 3. 
Table 3. Statistical comparisons between COSMIC RO (JPL/UCAR) and the near-coincident radiosonde (RDS).

\begin{tabular}{lrrrr}
\hline Mean errors & Altitude range & $\begin{array}{r}\text { JPL-RDS } \\
(65 \text { pairs })\end{array}$ & $\begin{array}{r}\text { UCAR-RDS } \\
(68 \text { pairs })\end{array}$ & $\begin{array}{r}\text { ERA-I-RDS } \\
(144 \text { pairs })\end{array}$ \\
\cline { 3 - 5 } & $(\mathrm{km})$ & $\mu(\sigma)$ & $\mu(\sigma)$ & $\mu(\sigma)$ \\
\hline$\Delta N / N_{\mathrm{RDS}}(\%)$ & $0-3$ & $-0.43(1.73)$ & $-0.50(1.58)$ & $-0.12(1.01)$ \\
& $0-5$ & $-0.29(1.46)$ & $-0.36(1.34)$ & $-0.21(0.94)$ \\
& $0-10$ & $-0.10(1.12)$ & $-0.20(0.99)$ & $-0.21(0.67)$ \\
\hline$\Delta T(\mathrm{~K})$ & $0-3$ & & $1.05(2.32)$ & $-0.17(1.22)$ \\
& $0-5$ & & $0.74(2.15)$ & $-0.05(1.07)$ \\
& $0-10$ & $0.62(1.94)$ & $0.53(2.06)$ & $0.12(0.96)$ \\
\hline$\Delta q\left(\mathrm{~g} \mathrm{~kg}^{-1}\right)$ & $0-3$ & $-0.16(0.67)$ & $-0.08(0.59)$ & $-0.003(0.39)$ \\
& $0-5$ & $-0.07(0.55)$ & $-0.08(0.49)$ & $-0.02(0.34)$ \\
& $0-10$ & & $-0.03(0.29)$ & $0.004(0.20)$ \\
\hline
\end{tabular}
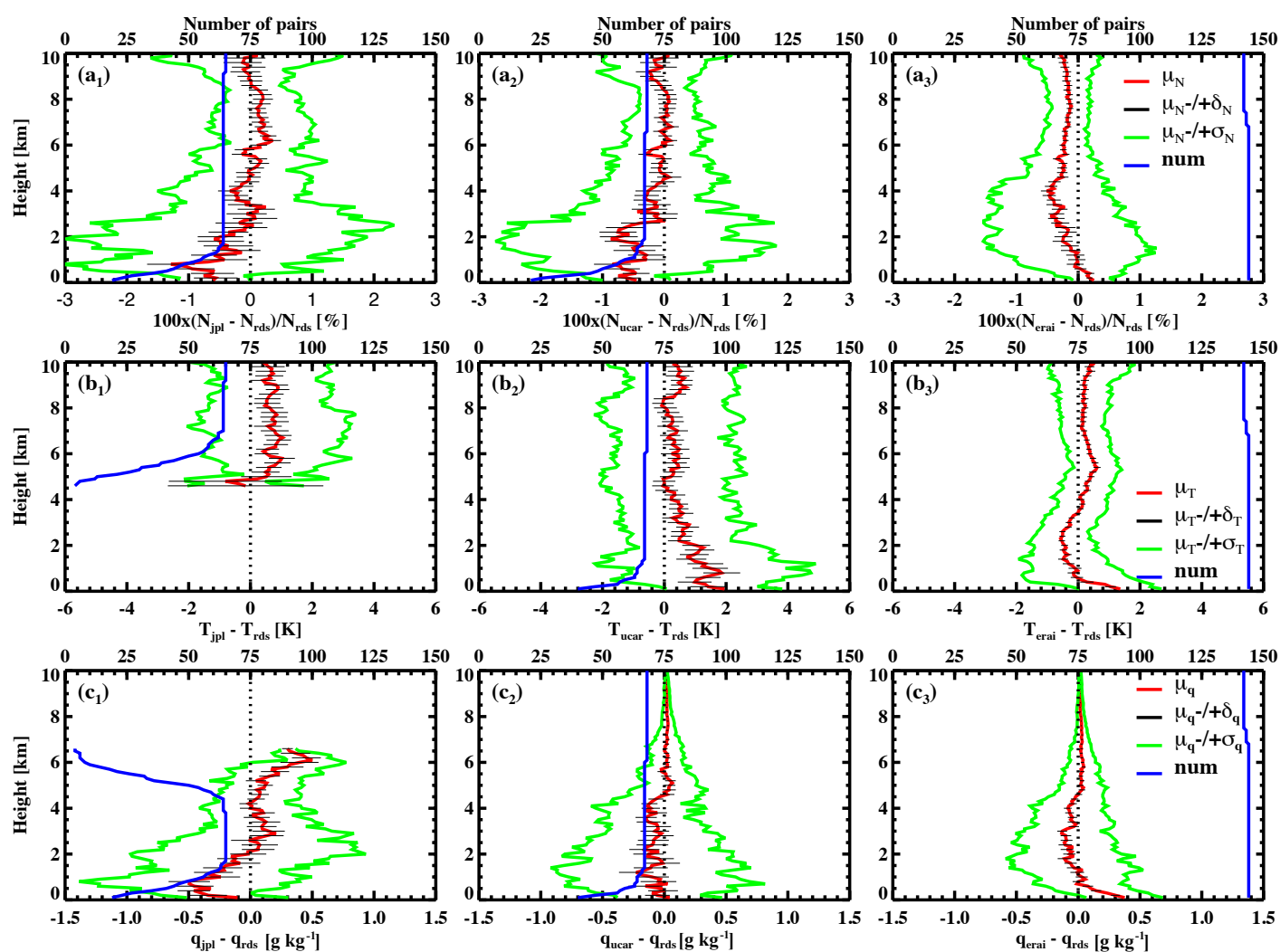

Figure 5. Difference between ASCOS radiosonde soundings and the near-coincident COSMIC RO from JPL (left), UCAR (middle), and ERA-I (right) in terms of fractional refractivity $\left(\mathbf{a}_{1}-\mathbf{a}_{3}\right)$, temperature $\left(\mathbf{b}_{1}-\mathbf{b}_{3}\right)$, and specific humidity $\left(\mathbf{c}_{1}-\mathbf{c}_{3}\right)$. The median difference $(\mu$, red), the median difference plus/minus $( \pm)$ median absolute deviation $(\sigma$, green), and median standard error $(\delta$, gray horizontal bar) for all three parameters are also shown. The number of near-coincident pairs as a function of height is shown in blue, with the scale marked on the top of each panel.

Compared with the radiosonde from the surface up to $10 \mathrm{~km}$, the COSMIC RO refractivity shows an overall median bias of $0.10 \%$ in JPL retrievals (Fig. $5 \mathrm{a}_{1}$ ), $-0.20 \%$ median bias in UCAR retrievals (Fig. $5 \mathrm{a}_{2}$ ), and $-0.21 \%$ overall median bias in ERA-I refractivity retrievals (Fig. 5a 3 ). How- ever, the overall JPL median bias $(0.10 \%)$ is comprised of both positive bias (e.g., $\sim 0.2 \%$ in $6-8 \mathrm{~km}$ ) and negative bias (e.g., $\sim-0.5 \%$ below $4 \mathrm{~km}$ ). Most of the negative bias is coming from the lower troposphere in JPL and UCAR. For example, JPL refractivity retrievals show a negative bias be- 
low $\sim 2 \mathrm{~km}$, which increases to a maximum of about $-1 \%$ in the lowest $1 \mathrm{~km}$ above the surface. Similarly, UCAR refractivity retrievals also show a negative bias, albeit starting from $\sim 5 \mathrm{~km}$ down to the surface, with a smaller maximum bias of about $-0.5 \%$. On the other hand, the ERA-I shows a generally negative bias above $\sim 1 \mathrm{~km}$ but a small positive mean bias below $\sim 0.5 \mathrm{~km}$.

Figure $5 b_{1}$ shows a warm bias of $0.62 \mathrm{~K}$ in JPL temperature retrievals from $10 \mathrm{~km}$ down to $\sim 4.5 \mathrm{~km}$, where JPL stops retrieving temperature. A sharp increase in standard error in JPL temperature below $5 \mathrm{~km}$ is due to the sharp drop in the available JPL temperature retrieval. On the other hand, UCAR temperature shows a smaller overall median bias of $0.53 \mathrm{~K}$ below $10 \mathrm{~km}$, with an increasing bias below $2 \mathrm{~km}$ up to near $2 \mathrm{~K}$ (Fig. $5 \mathrm{~b}_{2}$ ). ERA-I temperature shows a smallest overall median bias of $0.12 \mathrm{~K}$ below $10 \mathrm{~km}$ (Fig. $5 \mathrm{~b}_{3}$ ), with a warm bias $(\sim 1 \mathrm{~K})$ below $1 \mathrm{~km}$ and small cold bias above, which are consistent with Wesslén et al. (2014).

For specific humidity, the JPL retrievals exhibit negative biases from the surface up to $\sim 2 \mathrm{~km}$ and transition to positive biases above, with a median bias of about $0.07 \mathrm{~g} \mathrm{~kg}^{-1}$ from the surface up to $5 \mathrm{~km}$ (Fig. $5 \mathrm{c}_{1}$ ). The UCAR specific humidity has a negative overall bias of $-0.03 \mathrm{~g} \mathrm{~kg}^{-1}$, mostly coming from below $\sim 5 \mathrm{~km}$ (Fig. $5 \mathrm{c}_{2}$ ). The ERA-I specific humidity has an overall bias of $0.004 \mathrm{~g} \mathrm{~kg}^{-1}$, mostly coming from below $\sim 0.6 \mathrm{~km}$ (Fig. $5 \mathrm{c}_{3}$ ). It is also worth noting that the increasing biases and variations of RO refractivity, temperature, and specific humidity retrievals below $5 \mathrm{~km}$ strongly indicate the impact of the increasing availability and variation of water vapor in the Arctic summer on the RO retrievals.

Overall, JPL and UCAR refractivity retrievals are consistent with temperature and humidity retrievals (e.g., negative refractivity bias corresponding to positive bias of temperature and negative bias of the specific humidity), except at certain altitudes, where the JPL and radiosonde comparison shows positive fractional refractivity bias corresponding to positive temperature bias (e.g., 6-8 km), which may be affected by pressure. In the JPL retrieval, the refractivity errors are directly mapped into both temperature and humidity errors. In the UCAR 1-D-variational retrieval, the refractivity errors can be mapped to both/either temperature and/or humidity errors. In addition, the errors in the a priori information from ECMWF model analysis used for both JPL and UCAR will also affect the RO temperature and humidity retrieval. It is worth noting that the errors of the geophysical parameters derived from the 1-D-variational method in the UCAR retrieval become more challenging to interpret as they include errors from both the model background and the RO measurement. For instance, the errors of UCAR specific humidity are very similar to the ERA-I but not consistent with the refractivity errors, which indicate the model a priori humidity might dominate the 1 -D-variational UCAR humidity retrieval.
It is important to point out that the sharp drop in the number of near-coincidence profiles below $\sim 1 \mathrm{~km}$ (Fig. 5) is primarily due to the limited number of RO soundings penetrating deep into the PBL, especially the bottom $\sim 300 \mathrm{~m}$ above the surface.

\subsection{Comparisons between the $\mathrm{RO}$ retrievals and the ERA-I profiles}

To further quantify the parametric uncertainty, the COSMIC RO soundings from JPL and UCAR are also compared with the near-coincident ERA-I reanalysis profiles. Since the ERA-I assimilated COSMIC RO bending angles retrieved by the UCAR data center, they are not fully independent datasets. However, in the data assimilation, large RO measurement errors at lower altitudes (e.g., $20 \%$ in bending angles errors near the surface) are normally applied, along with a limited number of available RO soundings; the impact of RO sounding on ERA-I in the lower troposphere remains limited (Poli et al., 2010).

The total numbers of common COSMIC RO soundings from both JPL and UCAR are 4782 pairs in winter and 8375 pairs in summer of 2008 over the Arctic $\left(65-90^{\circ} \mathrm{N}\right)$. The comparison between COSMIC RO from the two centers and their near-coincident ERA-I profiles are presented in terms of fractional refractivity (Fig. 6), temperature (Fig. 7), and specific humidity (Fig. 8) differences. All profiles are interpolated into $100 \mathrm{~m}$ vertical intervals before the difference statistical calculation. Again, the statistics for the lowest $200 \mathrm{~m}$ were discarded due to the significant drop of the number of RO observations near the surface. The statistical differences between COSMIC RO and ERA-I at three selected altitude ranges (e.g., 3, 5, and $10 \mathrm{~km}$ from the surface) are detailed in Table 4.

In Fig. 6, the fractional refractivity difference between RO (JPL and UCAR) profiles and the near-coincident ERAI profiles shows small biases in winter. In the lowest $3 \mathrm{~km}$, JPL refractivity exhibits a small positive bias of $\sim 0.12 \%$, whereas UCAR has a smaller positive bias of $\sim 0.07 \%$. In summer, an increase in positive bias above $\sim 4 \mathrm{~km}$ and negative bias below $\sim 2 \mathrm{~km}$ are seen. The maximum negative bias reaches about $-0.7 \%(-0.6 \%)$ in the JPL (UCAR) retrieval near $0.5 \mathrm{~km}$. An average negative refractivity bias of about $-0.3 \%$ below $3 \mathrm{~km}$ is seen in both centers.

Similarly, Fig. 7 shows the temperature difference between COSMIC RO and the near-coincident ERA-I profiles. Below $3 \mathrm{~km}$, in winter, JPL shows a positive bias of $0.14 \mathrm{~K}$, whereas UCAR has a negative bias of $-0.12 \mathrm{~K}$. In summer, UCAR has a warm bias of $0.58 \mathrm{~K}$, whereas JPL does not have retrievals below $3 \mathrm{~km}$. Below $10 \mathrm{~km}$, temperature difference in winter (Fig. 7a, c) exhibits much smaller variation than that in summer. For instance, relatively large positive biases are seen in temperature retrievals from UCAR below $2 \mathrm{~km}$ (Fig. 7d) and from JPL within 6-10 km (Fig. 7b) as compared with the ERA-I profiles. 
Table 4. Statistical comparisons between COSMIC RO (JPL/UCAR) and the near-coincident ERA-Interim.

\begin{tabular}{lrrrrr}
\hline Mean difference & Altitude range & $\begin{array}{r}\text { UCAR-ERA-I DJF } \\
(4782 \text { pairs })\end{array}$ & $\begin{array}{r}\text { UCAR-ERA-I JJA } \\
(8375 \text { pairs })\end{array}$ & $\begin{array}{r}\text { JPL-ERA-I DJF } \\
(4782 \text { pairs })\end{array}$ & $\begin{array}{r}\text { JPL-ERA-I JJA } \\
(8375 \text { pairs })\end{array}$ \\
\cline { 3 - 6 } & $(\mathrm{km})$ & $\mu(\sigma)$ & $\mu(\sigma)$ & $\mu(\sigma)$ & $\mu(\sigma)$ \\
\hline$\Delta N / N(\%)$ & $0-3$ & $0.07(0.78)$ & $-0.26(1.63)$ & $0.12(0.78)$ & $-0.25(1.63)$ \\
& $0-5$ & $0.08(0.70)$ & $-0.11(1.45)$ & $0.13(0.70)$ & $-0.07(1.45)$ \\
& $0-10$ & $0.07(0.62)$ & $-0.05(1.04)$ & $0.13(0.62)$ & $0.12(1.04)$ \\
\hline$\Delta T(\mathrm{~K})$ & $0-3$ & $-0.12(1.83)$ & $0.58(2.25)$ & $0.14(1.83)$ & \\
& $0-5$ & $-0.13(1.63)$ & $0.31(2.00)$ & $0.20(1.63)$ & $0.25(1.65)$ \\
\hline$\Delta q\left(\mathrm{~g} \mathrm{~kg}^{-1}\right)$ & $0-10$ & $-0.14(1.36)$ & $0.11(1.65)$ & $0.15(1.36)$ & $-0.12(0.63)$ \\
& $0-3$ & $-0.02(0.17)$ & $-0.08(0.63)$ & $-0.002(0.17)$ & $-0.13)$ \\
& $0-5$ & $-0.01(0.13)$ & $-0.06(0.51)$ & $-0.001(0.13)$ & $-0.05(0.51)$ \\
& $0-10$ & $-0.01(0.08)$ & $-0.03(0.29)$ & $-0.001(0.08)$ & $-0.02(0.29)$ \\
\hline
\end{tabular}
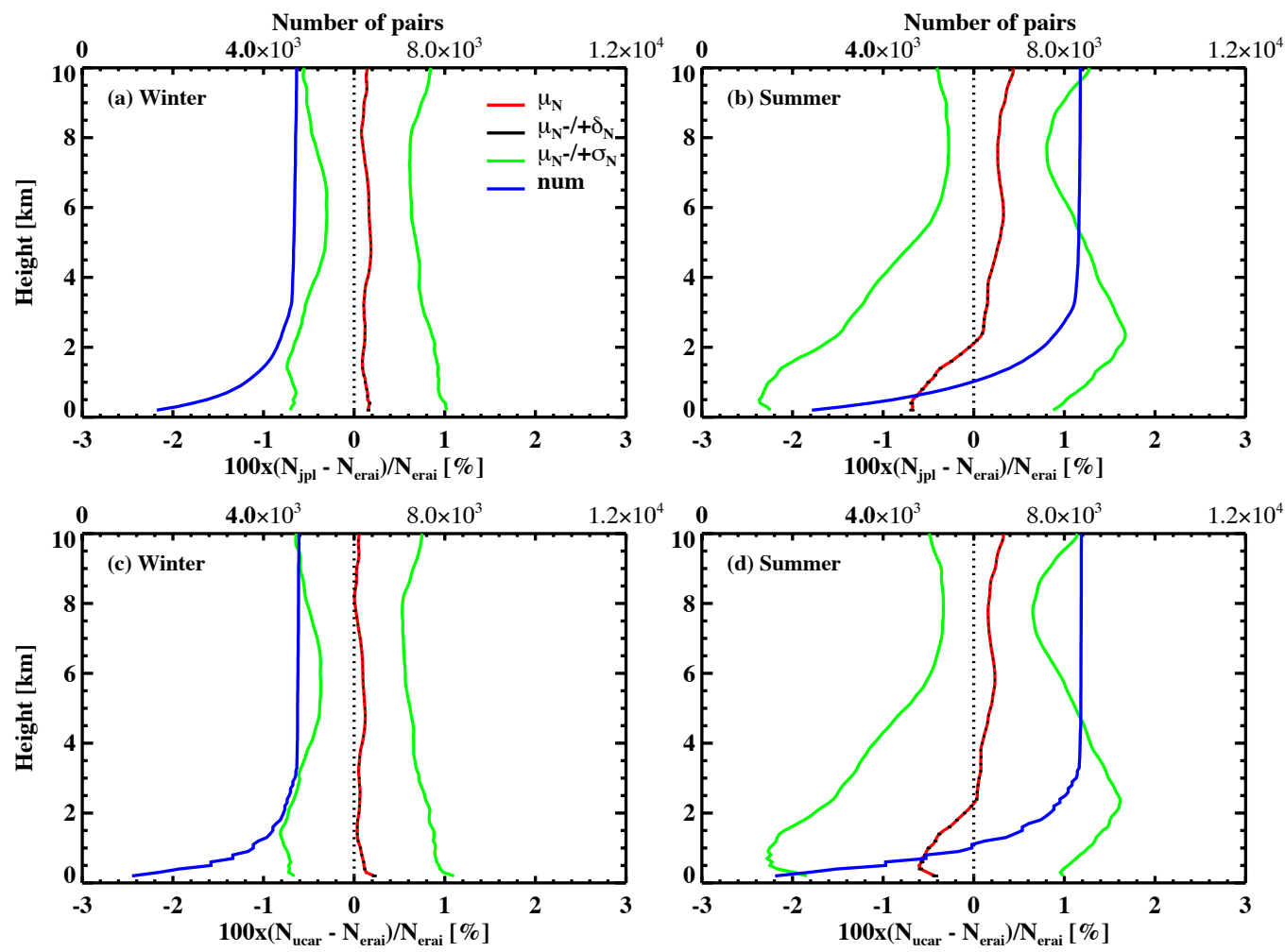

Figure 6. Fractional refractivity difference between COSMIC RO (JPL - top; UCAR - bottom) and the near-coincident ERA-I reanalysis over the Arctic $\left(65-90^{\circ} \mathrm{N}\right)$ during winter (DJF, a, c) and summer (JJA, b, d) of 2008. The mean difference (red), mean plus/minus 1 standard deviation (black), and number of RO profiles that penetrated down to a given altitude (blue) are shown.

Moreover, Fig. 8 shows the difference between the specific humidity retrievals from COSMIC RO and the nearcoincident ERA-I. Within $3 \mathrm{~km}$, JPL and UCAR have a negligible bias of -0.002 and $-0.02 \mathrm{~g} \mathrm{~kg}^{-1}$, respectively, in winter. In summer, much larger dry biases of about -0.12 in JPL and $-0.08 \mathrm{~g} \mathrm{~kg}^{-1}$ in UCAR retrievals are detected. Overall, the RO specific humidity exhibits negative biases below
$2 \mathrm{~km}$, likely due to the abundant water vapor near the ocean surface.

In summary, the COSMIC RO (JPL or UCAR) refractivity difference from the near-coincident ERA-I retrievals is consistent with the temperature and humidity retrieval differences (e.g., negative refractivity bias corresponding to positive bias in temperature and negative bias in the specific humidity). However, positive fractional refractivity bias corre- 

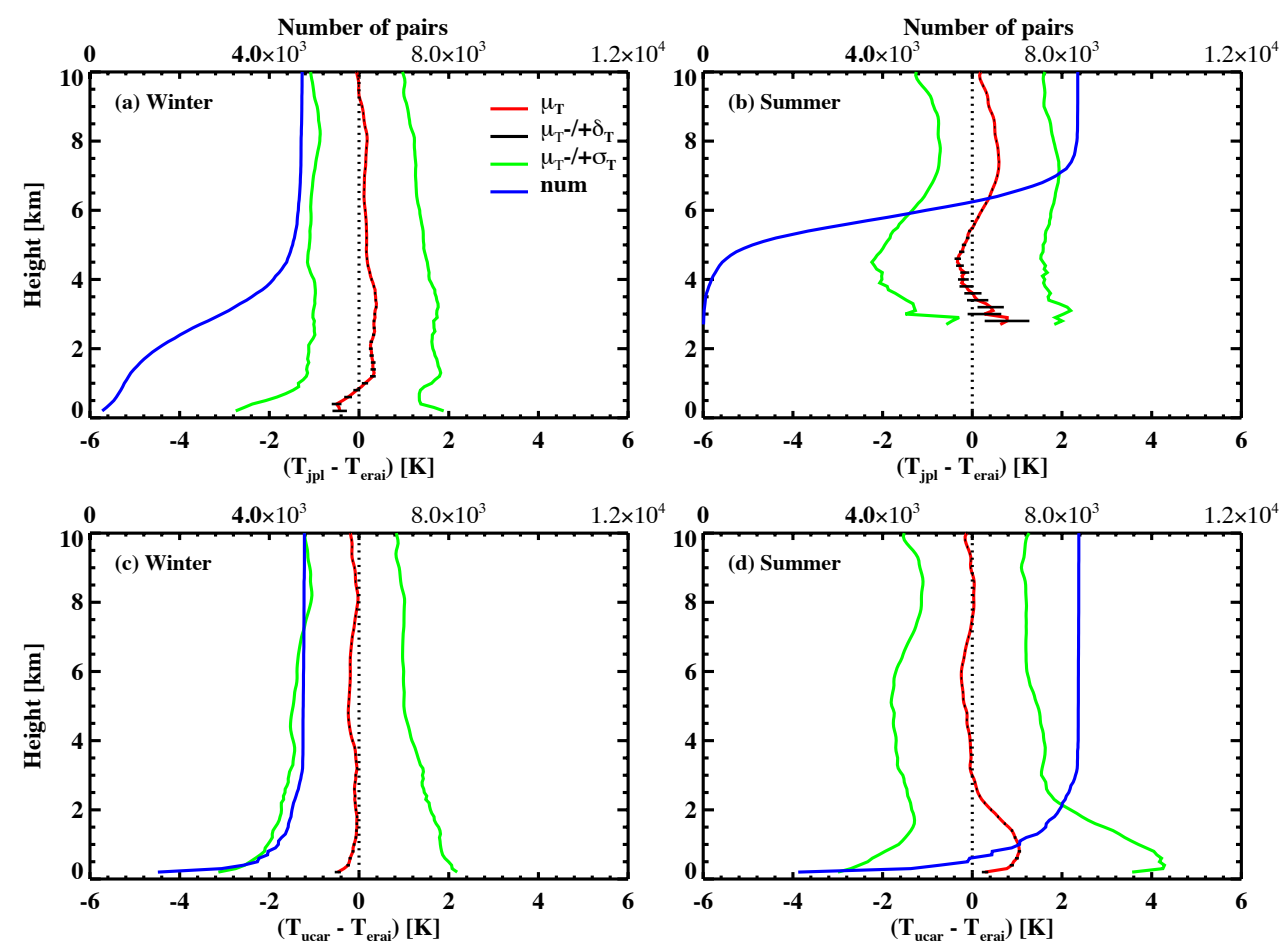

Figure 7. Same as Fig. 6 but for temperature difference (K) between COSMIC RO and ERA-I.
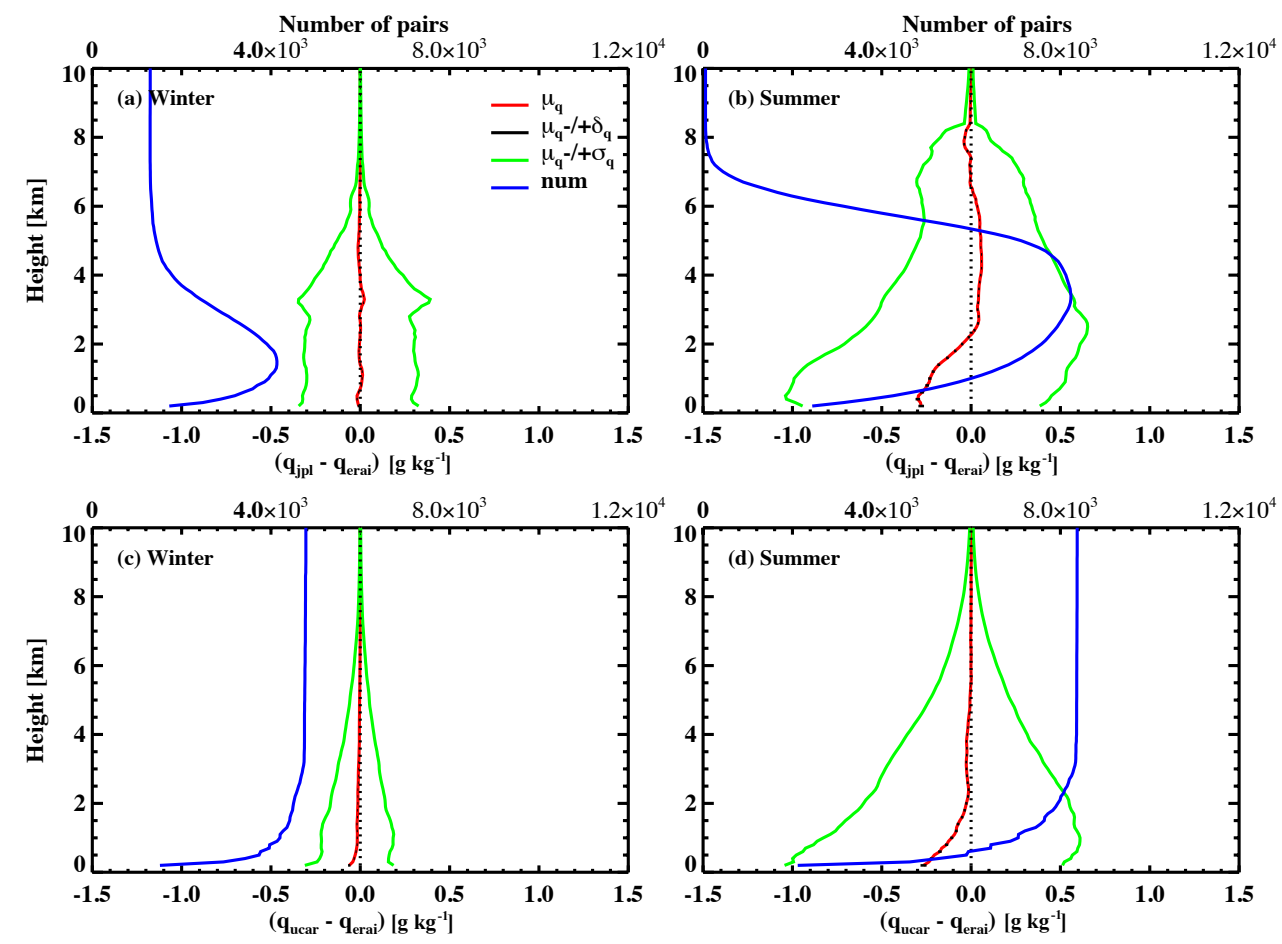

Figure 8. Same as Fig. 6 but for specific humidity difference $\left(\mathrm{g} \mathrm{kg}^{-1}\right)$ between COSMIC RO and ERA-I. 

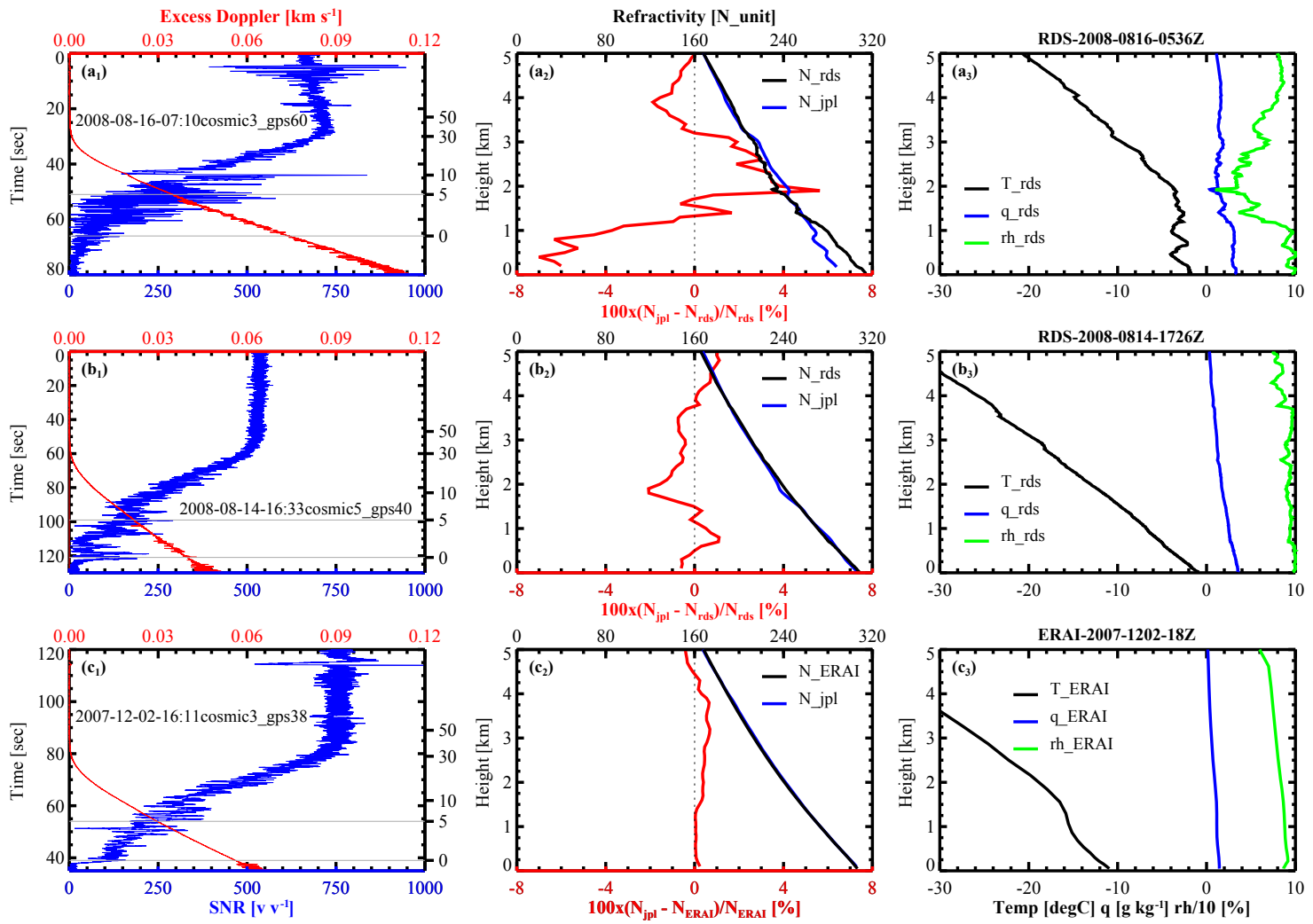

Figure 9. Three COSMIC RO soundings along with the near-coincident ASCOS radiosonde in summer (a, b) and ERA-I profile in winter (c). (Left) the COSMIC L1 SNR (blue) and excess Doppler (red) from JPL retrievals with the estimated tangent height shown on the right $y$ axis, and the two horizontal thin lines indicating the surface and $5 \mathrm{~km}$ altitude; (center) JPL RO refractivity (blue) and the near-coincident radiosonde and ERA-I profiles (black), along with the fractional refractivity difference (red); (right) radiosonde and ERA-I profiles of temperature (black), specific humidity (blue), and 1/10 of relative humidity (green).

sponds to positive temperature bias in JPL retrievals. Most of the mean biases have negligible standard errors due to large sample sizes.

\subsection{Case study of RO signal dynamics}

To further study the impact of moisture on the RO soundings, the L1 signal-to-noise ratio (SNR) and excess Doppler for two typical JPL COSMIC RO soundings from summer $(a, b)$ and one from winter (c) were presented along with the near-coincident ASCOS radiosonde (in summer) and the ERA-I profiles (in winter; Fig. 9). The two summer cases show nearly double the moisture with specific humidity $\left(\sim 2 \mathrm{~g} \mathrm{~kg}^{-1}\right)$ near the surface than that in the winter (less than $\sim 1 \mathrm{~g} \mathrm{~kg}^{-1}$ ). In the winter case, very smooth excess Doppler along with a relatively quiet SNR is shown. A sharp drop in SNR to the noise background is clearly seen around $39 \mathrm{~s}$ (Fig. 9 $\mathrm{c}_{1}$ ), when tangent point descends to the smooth Arctic Ocean surface. In contrast, much larger variations in both the SNR and excess Doppler are seen in the two summer cases, especially below $5 \mathrm{~km}$. The transition of the SNR to noise background near the surface is smeared due to more lower-troposphere moisture variations, which likely introduce multipath and SNR variations. Even though the lower-troposphere moisture in Arctic summer is still rather low (less than $2 \mathrm{~g} \mathrm{~kg}^{-1}$ near the surface) as compared to the low latitudes, a surprisingly large difference in refractivity ( $-7 \%$ near surface) is seen (Fig. 9a2). The systematic negative RO $N$ bias ( $-1 \%$ ) in summer season (e.g., Figs. 5 and 6) could be directly attributed to the lower-troposphere moisture variations. However, the impact of moisture and its variations on the RO signal dynamics and so the RO calibration and retrieval processes warrant a more comprehensive investigation.

\section{Summary and conclusions}

In summary, over the Arctic $\left(65-90^{\circ} \mathrm{N}\right)$, 3-year (20082010) COSMIC RO soundings show uniform spatial sampling with average penetration depth (the minimum profile height) within $300 \mathrm{~m}$ above the ocean surface. The fraction of the deeply penetrating COSMIC soundings (within $300 \mathrm{~m}$ ) is over $70 \%$ in all non-summer seasons but reduces to only 50 $60 \%$ in the summer. The increase of the near-surface mois- 
ture and its variation in summer, even though relatively small compared to the tropics, can lead to significant GPS RO SNR and excess Doppler variations, which could complicate the GPS RO signal tracking and lead to early sounding termination before reaching the surface.

Both structural uncertainty and parametric uncertainty of COSMIC RO soundings have been quantified. The structural uncertainty of RO is estimated by comparing the retrieved refractivity, temperature, and specific humidity from JPL and UCAR processing centers, which process the same raw COSMIC GPS data. The comparisons using 1-year COSMIC data in 2008 show the inter-center RO retrieval difference (i.e., structural uncertainty) within $\sim 0.07 \%$ in refractivity, $\sim 0.72 \mathrm{~K}$ in temperature, and $\sim 0.05 \mathrm{~g} \mathrm{~kg}^{-1}$ in specific humidity below $10 \mathrm{~km}$. The parametric uncertainty is quantified by comparing RO with the near-coincident radiosonde and the ERA-I reanalysis. COSMIC RO shows slightly larger difference from the near-coincident radiosondes than the ERAI, which assimilated UCAR COSMIC RO retrievals. A systematic negative bias up to $\sim 1 \%$ in refractivity below $2 \mathrm{~km}$ is only observed during the summer, which further confirms the impact of the lower-tropospheric summer moisture on RO retrievals. The parametric uncertainty of the COSMIC RO refractivity sounding in the summer season is about 2 orders of magnitude larger than the structural uncertainty, implying highly consistent, precise COSMIC RO observations in the troposphere. It is reasonable to expect the parametric uncertainty in the winter season to be even smaller due to much less impact of moisture on the $\mathrm{RO}$ retrievals.

In conclusion, GPS RO provides high-quality measurement (especially in refractivity) in the lower troposphere over the Arctic. The high-precision COSMIC RO measurements with uniform spatial and temporal sampling provide a promising opportunity for studying the lower-tropospheric dynamic process, especially the PBL study. However, the early termination of RO sounding before reaching the surface and the systematic RO refractivity bias inside the PBL in summer limit the RO sounding capability inside the PBL and impede its application for the physical process study involving the interaction of ocean, atmosphere, and sea ice. Preliminary study shows the impact of moisture on the RO signal dynamics. Further study is needed to improve the RO sounding quality and to enhance the scientific application of RO observations in the lower troposphere.

Data availability. The data generated in this study are available from the corresponding author upon request.

Competing interests. The authors declare that they have no conflict of interest.
Special issue statement. This article is part of the special issue "Observing Atmosphere and Climate with Occultation Techniques - Results from the OPAC-IROWG 2016 Workshop". It is a result of the International Workshop on Occultations for Probing Atmosphere and Climate, Leibnitz, Austria, 8-14 September 2016.

Acknowledgements. This research was partially supported by NASA (grants NNX14AK17G and NNX15AQ17G), NSF (grant AGS-1262041), and the Research Commercialization Outreach Office of Texas A\&M University - Corpus Christi. The authors also acknowledge the NASA Jet Propulsion Laboratory (JPL) Education Office for the summer internship opportunity in supporting the lead author. COSMIC GPS radio occultation soundings were obtained from the Jet Propulsion Laboratory (https://genesis.jpl.nasa.gov/genesis/) and the University Corporation for Atmospheric Research (http://cdaac-www.cosmic.ucar.edu/cdaac/products.html).

The ASCOS radiosonde soundings were provided by Professor Michael Tjernström from Stockholm University. The ERA-Interim data were obtained from ECMWF (http: //apps.ecmwf.int/datasets/data/interim-full-daily/levtype=sfc/).

Edited by: Andrea K. Steiner

Reviewed by: three anonymous referees

\section{References}

Anthes, R. A., Bernhardt, P. A., Chen, Y., Cucurull, L., Dymond, K. F., Ector, D., Healy, S. B., Ho, S. P., Hunt, D. C., Kuo, Y. H., Liu, H., Manning, K., McCormick, C., Meehan, T. K., Randel, W. J., Rocken, C., Schreiner, W. S., Sokolovskiy, S. V., Syndergaard, S., Thompson, D. C., Trenberth, K. E., Wee, T. K., Yen, N. L., and Zeng, Z.: The COSMIC/Formosat-3 mission: Early results, B. Am. Meteorol. Soc., 89, 313-333, https://doi.org/10.1175/BAMS-89-3-313, 2008.

Ao, C. O., Meehan, T. K., Hajj, G. A., Manucci, A. J., and Beyerle, G.: Lower troposphere refractivity bias in GPS occultation retrievals, J. Geophys. Res., 108, 4577, https://doi.org/10.1029/2002JD003216, 2003.

Ao, C. O., Hajj, G. A., Meehan, T. K., Dong, D., Iijima, B. A., Mannucci, A. J., and Kursinski, E. R.: Rising and setting GPS occupations by use of open-loop tracking, J. Geophys. Res.-Atmos., 114, 1-15, https://doi.org/10.1029/2008JD010483, 2009.

Ao, C. O., Waliser, D. E., Chan, S. K., Li, J. L., Tian, B., Xie, F., and Mannucci, A. J.: Planetary boundary layer heights from GPS radio occultation refractivity and humidity profiles, J. Geophys. Res.-Atmos., 117, 1-18, https://doi.org/10.1029/2012JD017598, 2012.

Bernstein, L., Bosch, P., Canziani, O., Chen, Z., Christ, R., Davidson, O., Hare, W., Huq, S., Karoly, D., Kattsov, V., Kundzewicz, Z., Liu, J., Lohmann, U., Manning, M., Matsuno, T., Menne, B., Metz, B., Mirza, M., Nicholls, N., Nurse, L., Pachauri, R., Palutikof, J., Parry, M., Qin, D., Ravindranath, N., Reisinger, A., Ren, J., Riahi, K., Rosenzweig, C., Rusticucci, M., Sch-Neider, S., Sokona, Y., Solomon, S., Stott, P., Stouffer, R., Sugiyama, T., Swart, R., Tirpak, D., Vogel, C., Yohe, G., Nottage, R., and Madan, P.: Climate Change 2007 Synthesis Report The Core 
Writing Team Rajendra K, Pachauri Andy Reisinger Synthesis Report Chairman Head, Technical Support Unit IPCC IPCC Synthesis Report, IPCC Core Writing Team Technical Support Unit for the Synthesis Report, 2007.

Birch, C. E., Brooks, I. M., Tjernström, M., Shupe, M. D., Mauritsen, T., Sedlar, J., Lock, A. P., Earnshaw, P., Persson, P. O. G., Milton, S. F., and Leck, C.: Modelling atmospheric structure, cloud and their response to $\mathrm{CCN}$ in the central Arctic: ASCOS case studies, Atmos. Chem. Phys., 12, 3419-3435, https://doi.org/10.5194/acp-12-3419-2012, 2012.

Chae, Y., Kang, S. M., Jeong, S., Kim, B., and Frierson, D. M. W.: Arctic greening can cause earlier seasonality of Arctic amplification, Geophys. Res. Lett., 42, 536-541, https://doi.org/10.1002/2014GL061841, 2015.

Chang L., Song, S., Feng, G., Zhang, Y., and Gao, G.: Assessment of the Uncertainties in Arctic Low-Level Temperature Inversion Characteristics in Radio Occultation Observations, IEEE T. Geosci. Remote, 55, 1793-1803, 2017.

Cucurull, L., Derber, J. C., Treadon, R., and Purser, R. J.: Preliminary Impact Studies Using Global Positioning System Radio Occultation Profiles at NCEP, Mon. Weather Rev., 136, 1865-1877, https://doi.org/10.1175/2007MWR2260.1, 2008.

Dee, D. P., Uppala, S. M., Simmons, A. J., Berrisford, P., Poli, P., Kobayashi, S., Andrae, U., Balmaseda, M. A., Balsamo, G., Bauer, P., Bechtold, P., Beljaars, A. C. M., van de Berg, L., Bidlot, J., Bormann, N., Delsol, C., Dragani, R., Fuentes, M., Geer, A. J., Haimberger, L., Healy, S. B., Hersbach, H., Hólm, E. V., Isaksen, L., Kållberg, P., Köhler, M., Matricardi, M., Mcnally, A. P., Monge-Sanz, B. M., Morcrette, J. J., Park, B. K., Peubey, C., de Rosnay, P., Tavolato, C., Thépaut, J. N., and Vitart, F.: The ERA-Interim reanalysis: Configuration and performance of the data assimilation system, Q. J. Roy. Meteor. Soc., 137, 553-597, https://doi.org/10.1002/qj.828, 2011.

Deng, G., Zhang, D., Zhu, T., and Wang, A.: Use of the advanced microwave sounding unit data to improve typhoon prediction, Prog. Nat. Sci., 19, 369-376, https://doi.org/10.1016/j.pnsc.2008.08.001, 2009.

Ganeshan, M. and Wu, D. L.: An investigation of the Arctic inversion using COSMIC RO observations, J. Geophys. Res.-Atmos., 120, 9338-9351, https://doi.org/10.1002/2015JD023058, 2015.

Hajj, G. A., Kursinski, E. R., Romans, L. J., Bertiger, W. I., and Leroy, S. S.: A Technical Description of Atmospheric Sounding By Gps, System, 64, 451-469, 2002.

Healy, S. and Eyre, J.: Retrieving temperature, water vapour and surface pressure information from refractive-index profiles derived by radio occultation: A simulation study, Q. J. Roy. Meteor. Soc., 126, 1661-1683, https://doi.org/10.1002/qj.49712656606, 2000.

Healy, S. B., Jupp, A. M., and Marquardt, C.: Forecast impact experiment with GPS radio occultation measurements, Geophys. Res. Lett., 32, 1-4, https://doi.org/10.1029/2004GL020806, 2005.

Ho, S. P., Kirchengast, G., Leroy, S., Wickert, J., Mannucci, A. J., Steiner, A., Hunt, D., Schreiner, W., Sokolovskiy, S., Ao, C., Borsche, M., Von Engeln, A., Foelsche, U., Heise, S., Iijima, B., Kuo, Y. H., Kursinski, R., Pirscher, B., Ringer, M., Rocken, C., and Schmidt, T.: Estimating the uncertainty of using GPS radio occultation data for climate monitoring: Intercomparison of CHAMP refractivity climate records from 2002 to 2006 from different data centers, J. Geophys. Res.-Atmos., 114, 1-20, https://doi.org/10.1029/2009JD011969, 2009.

Ho, S.-P., Hunt, D., Steiner, A. K., Mannucci, A. J., Kirchengast, G., Gleisner, H., Heise, S., von Engeln, A., Marquardt, C., Sokolovskiy, S., Schreiner, W., Scherllin-Pirscher, B., Ao, C., Wickert, J., Syndergaard, S., Lauritsen, K. B., Leroy, S., Kursinski, E. R., Kuo, Y.-H., Foelsche, U., Schmidt, T., and Gorbunov, M.: Reproducibility of GPS radio occultation data for climate monitoring: Profile-to-profile inter-comparison of CHAMP climate records 2002 to 2008 from six data centers, J. Geophys. Res., 117, D18111, https://doi.org/10.1029/2012JD017665, 2012.

Ho, S.-P., Peng, L., Anthes, R.A., Kuo, Y.-H., and Lin, H.-C.: Marine boundary layer heights and their longitudinal, diurnal, and interseasonal variability in the southeastern Pacific using COSMIC, CALIOP, and radiosonde data, J. Climate, 28, 2856-2872, https://doi.org/10.1175/JCLI-D-14-00238.1, 2015.

Jensen, A. S., Lohmann, M. S., Benzon, H. H., and Nielsen, A. S.: Full spectrum inversion of radio occultation signals, Radio Sci., 38, 1-15, https://doi.org/10.1029/2002RS002763, 2003.

John, V. O. and Buehler, S. A.: Comparison of microwave satellite humidity data and radiosonde profiles: A survey of European stations, Atmos. Chem. Phys., 5, 1843-1853, https://doi.org/10.5194/acp-5-1843-2005, 2005.

Kuo, Y.-H., Wee, T.-K., Sokolovskiy, S., Rocken, C., Schreiner, W., Hunt, D., and Anthes, R.: Inversion and Error Estimation of GPS Radio Occultation Data, J. Meteorol. Soc. Jpn., 82, 507-531, https://doi.org/10.2151/jmsj.2004.507, 2004.

Kuo, Y. H., Schreiner, W. S., Wang, J., Rossiter, D. L., and Zhang, Y.: Comparison of GPS radio occultation soundings with radiosondes, Geophys. Res. Lett., 32, 1-4, https://doi.org/10.1029/2004GL021443, 2005.

Kursinski, E. R., Hajj, G. A., Schofield, J. T., Linfield, R. P., and Hardy, K. R.: Observing Earth's atmosphere with radio occultation measurements using the Global Positioning System, J. Geophys. Res., 102, 23429, https://doi.org/10.1029/97JD01569, 1997.

Kursinski, E. R., Hajj, G. A., Leroy, S. S., and Herman, B. M.: The GPS radio occultation technique, Tao, 11, 53-114, 2000.

Melbourne, W. G.: Radio Occultations Using Earth Satellites: A Wave Theory Treatment, Deep Sp. Commun. Navig. Ser., 6, 0635, 2004.

Najafi, M. R., Zwiers, F. W., and Gillett, N. P.: Attribution of Arctic temperature change to greenhouse-gas and aerosol influences, Nature Climate Change, 5, 246-249, https://doi.org/10.1038/nclimate2524, 2015.

Pelliccia, F., Pacifici, F., Bonafoni, S., Basili, P., Pierdicca, N., Ciotti, P., and Emery, W. J.: Neural networks for arctic atmosphere sounding from radio occultation data, IEEE T. Geosci. Remote, 49, 4846-4855, https://doi.org/10.1109/TGRS.2011.2153859, 2011.

Poli, P., Healy, S. B., and Dee, D. P.: Assimilation of Global Positioning System radio occultation data in the ECMWF ERAInterim reanalysis, Q. J. Roy. Meteor. Soc., 136, 1972-1990, https://doi.org/10.1002/qj.722, 2010.

Rossow, W. B. and Schiffer, R. A.: ISCCP cloud data products, B. Am. Meteorol. Soc., 71, 2-20, 1991.

Schreiner, W., Rocken, C., Sokolovskiy, S., and Hunt, D.: Quality assessment of COSMIC/FORMOSAT-3 GPS radio occul- 
tation data derived from single- and double-difference atmospheric excess phase processing, GPS Solut., 14, 13-22, https://doi.org/10.1007/s10291-009-0132-5, 2009.

Smith, E. K. and Weintraub, S.: The Constants in the Equation for Atmospheric Refractive Index at Radio Frequencies, P. IRE, 41, 39-41, https://doi.org/10.1109/JRPROC.1953.274297, 1953.

Sokolovskiy, S., Rocken, C., Hunt, D., Schreiner, W., Johnson, J., Masters, D., and Esterhuizen, S.: GPS profiling of the lower troposphere from space: Inversion and demodulation of the openloop radio occultation signals, Geophys. Res. Lett., 33, 1-5, https://doi.org/10.1029/2006GL026112, 2006a.

Sokolovskiy, S., Kuo, Y. H., Rocken, C., Schreiner, W. S., Hunt, D., and Anthes, R. A.: Monitoring the atmospheric boundary layer by GPS radio occultation signals recorded in the open-loop mode, Geophys. Res. Lett., 33, 10-13, https://doi.org/10.1029/2006GL025955, 2006b.

Sokolovskiy, S., Rocken, C., Schreiner, W., and Hunt, D.: On the uncertainty of radio occultation inversions in the lower troposphere, J. Geophys. Res.-Atmos., 115, 1-19, https://doi.org/10.1029/2010JD014058, 2010.

Sokolovskiy, S. V., Rocken, C., Lenschow, D. H., Kuo, Y. H., Anthes, R. A., Schreiner, W. S., and Hunt, D. C.: Observing the moist troposphere with radio occultation signals from COSMIC, Geophys. Res. Lett., 34, 1-6, https://doi.org/10.1029/2007GL030458, 2007.

Steiner, A. K., Hunt, D., Ho, S.-P., Kirchengast, G., Mannucci, A. J., Scherllin-Pirscher, B., Gleisner, H., von Engeln, A., Schmidt, T., Ao, C., Leroy, S. S., Kursinski, E. R., Foelsche, U., Gorbunov, M., Heise, S., Kuo, Y.-H., Lauritsen, K. B., Marquardt, C., Rocken, C., Schreiner, W., Sokolovskiy, S., Syndergaard, S., and Wickert, J.: Quantification of structural uncertainty in climate data records from GPS radio occultation, Atmos. Chem. Phys., 13, 1469-1484, https://doi.org/10.5194/acp13-1469-2013, 2013.

Thorne, P. W., Parker, D. E., Christy, J. R., and Mears, C. A.: Uncertainties in climate trends: Lessons from upper-air temperature records, B. Am. Meteorol. Soc., 86, 1437-1442, https://doi.org/10.1175/BAMS-86-10-1437, 2005.

Tjernström, M., Leck, C., Birch, C. E., Bottenheim, J. W., Brooks, B. J., Brooks, I. M., Bäcklin, L., Chang, R. Y.-W., de Leeuw, G., Di Liberto, L., de la Rosa, S., Granath, E., Graus, M., Hansel, A., Heintzenberg, J., Held, A., Hind, A., Johnston, P., Knulst, J., Martin, M., Matrai, P. A., Mauritsen, T., Müller, M., Norris, S. J., Orellana, M. V., Orsini, D. A., Paatero, J., Persson, P. O. G., Gao, Q., Rauschenberg, C., Ristovski, Z., Sedlar, J., Shupe, M. D., Sierau, B., Sirevaag, A., Sjogren, S., Stetzer, O., Swietlicki, E., Szczodrak, M., Vaattovaara, P., Wahlberg, N., Westberg, M., and Wheeler, C. R.: The Arctic Summer Cloud Ocean Study (ASCOS): overview and experimental design, Atmos. Chem. Phys., 14, 2823-2869, https://doi.org/10.5194/acp14-2823-2014, 2014. von Engeln, A., Teixeira, J., Wickert, J., and Buehler, S. A.: Using CHAMP radio occultation data to determine the top altitude of the Planetary Boundary Layer, Geophys. Res. Lett., 32, 1-4, https://doi.org/10.1029/2004GL022168, 2005.

Vihma, T.: Effects of Arctic Sea Ice Decline on Weather and Climate: A Review, Surv. Geophys., 35, 1175-1214, https://doi.org/10.1007/s10712-014-9284-0, 2014.

Weng, F., Wang, K., and Zou, X.: 30-Year Atmospheric Temperatures Derived from Satellite Microwave Sounding Instruments Using a 1-D-Var Approach 1, National Environmental Satellite, Data \& Information Service, National Oceanic and Atmospheric Administration 2, Earth System Science Int, 2012.

Wesslén, C., Tjernström, M., Bromwich, D. H., de Boer, G., Ekman, A. M. L., Bai, L.-S., and Wang, S.-H.: The Arctic summer atmosphere: an evaluation of reanalyses using ASCOS data, Atmos. Chem. Phys., 14, 2605-2624, https://doi.org/10.5194/acp14-2605-2014, 2014.

Wickert, J.: GPS radio occultation with CHAMP: Atmospheric profiling utilizing the space-based single difference technique, Geophys. Res. Lett., 29, 1-4, https://doi.org/10.1029/2001GL013982, 2002.

Xie, F., Wu, D. L., Ao, C. O., Mannucci, A. J., and Kursinski, E. R.: Advances and limitations of atmospheric boundary layer observations with GPS occultation over southeast Pacific Ocean, Atmos. Chem. Phys., 12, 903-918, https://doi.org/10.5194/acp12-903-2012, 2012.

Zou, X., Kuo, Y.-H., and Guo, Y.-R.: Assimilation of Atmospheric Radio Refractivity Using a Nonhydrostatic Adjoint Model, Mon. Weather Rev., 123, 2229-2249, https://doi.org/10.1175/15200493(1995)123<2229:AOARRU>2.0.CO;2, 1995.

Zygmuntowska, M., Mauritsen, T., Quaas, J., and Kaleschke, L.: Arctic Clouds and Surface Radiation - a critical comparison of satellite retrievals and the ERA-Interim reanalysis, Atmos. Chem. Phys., 12, 6667-6677, https://doi.org/10.5194/acp-126667-2012, 2012. 